\title{
G) Citicatórica
}

\section{"A aparência que dá o tom": gênero, corpo e beleza nas cenas dos filmes Shrek}

\author{
"La apariencia que da el tono": \\ género, cuerpo y belleza en las escenas de las películas Shrek
}

Renata Santos Maia*

Resumo: As mídias são poderosas formadoras de representações sociais, de subjetivação e criadoras de padrões de beleza, e o cinema de animação é um importante difusor desses padrões desde a infância. Analiso, neste artigo, algumas temáticas presentes nos filmes Shrek que abordam as polaridades criadas nos roteiros dos contos de fadas, como: feiura versus beleza, personagens maus em contraposição aos personagens bons, a norma contra a diferença e de que forma essas características aparecem associadas às concepções sobre o corpo e a beleza.

Palavras-chave: Gênero, corpo, cinema de animação.

Resumén: Los medios son poderosas formadoras de representaciones sociales, de subjetivación y creadoras de patrones de belleza, y el cine de animación es un importante difusor de esos patrones desde la infancia. En este artículo se analizan algunas temáticas presentes en las películas Shrek que abordan las polaridades creadas en los guiones de los cuentos de hadas, como: fehura versus belleza, personajes malvados en contraposición a los personajes buenos, la norma contra la diferencia y de qué forma esas características aparecen asociadas a las concepciones sobre el cuerpo y la belleza.

Palabras clave: Género, cuerpo, cine de animación.

\section{Introdução}

Ao fazer uma articulação entre gênero e mídia, quero evidenciar neste artigo como determinados discursos sobre os corpos masculinos e femininos constroem verdades; e

\footnotetext{
* Doutoranda em História Cultural pela Universidade Federal de Santa Catarina - UFSC, onde desenvolve estudos sobre gênero, cinema, sexualidades e feminismos; é mestre em História Social pela Universidade Estadual de Montes Claros - Unimontes - e está vinculada ao Laboratório de Estudos de Gênero e História (LEGH), da UFSC. Bolsista Capes.
} 
como determinadas mídias (entre as quais está o cinema de animação) operam como influentes instrumentos de incentivo ao consumo e ditadores de modelos ideais de aparência, associando-os aos sentimentos de felicidade pessoal e no relacionamento conjugal.

Dessa forma, se antes tínhamos o discurso médico como uma das principais tecnologias de gênero a difundir normas e "verdades" sobre os corpos, hoje temos, com grande força e alcance, o discurso midiático que, além de ser "um meio poderoso de criar e fazer circular conteúdos simbólicos, possui um poder transformador [...] de reestruturação dos espaços de interação propiciando novas configurações aos esforços de produção de sentido". (SPINK; MEDRADO, 20I3, p. 38)

Entre esses discursos está o cinema, que age de forma bastante sutil e pode ser considerado uma importante tecnologia de gênero que veicula padrões de beleza, modelos de corporeidade e formas de comportamento não só para as mulheres, mas também para homens e crianças. Eliane Teixeira Lopes, no prefácio de A mulher vai ao cinema, cita alguns exemplos, como o da atriz mirim Shirley Temple que além de tornar-se um arquétipo infantil fazendo com que se pensasse que "as crianças deveriam ser bonitas, inteligentes, espertas, comoventes, elegantes tal como ela" (LOPES, 2008, p. I2), também lançou diversos produtos que levavam seu nome e rosto, como bonecas e livros, e chegou a aparecer como personagem em alguns desenhos da Disney.

De acordo com Teixeira Lopes (2008, p. 12), o star system convertia artistas em mitos, por isso "era chique e revelava contemporaneidade estar entrosado com o que atrizes e atores vestiam", e até hoje essa influência se perpetua, não só em relação ao vestuário, mas através da cor e cortes de cabelo, formato do corpo e uso de acessórios. Ela destaca que, a partir dos anos 1980, uma masculinidade marcada pela violência e posturas implacáveis surge personificada nas figuras de Rambo e Robocop, entre outros, que mostram corpos exalando "uma hipermasculinidade, marcada pelos músculos esculpidos nos exercícios e nas lutas, ou produzida por incríveis combinações humano-tecnológicas, em que o corpo-máquina potencializa as habilidades e poderes do homem" (LOPES, 2008, p. I5).

A indústria cinematográfica dos Estados Unidos - Hollywood - reforçou o culto à juventude, "os rostos adolescentes, maquiados segundo um roteiro de mulher fatal, conheceram um sucesso inusitado. Eles foram os grandes divulgadores das novas formas de cuidar do corpo" (SANT'ANNA, 2012, p. IO7). A influência de atrizes famosas no cinema como 
Louise Brooks e seu corte à la garçonne ${ }^{\mathrm{I}}$ provocou uma verdadeira febre entre as mulheres. $\mathrm{O}$ novo look, além de estar sintonizado com a moda, também passou a marcar uma postura social e política de mulheres que buscavam um estilo mais ousado e independente na maneira de se comportar (SANT'ANNA, 2012). Por outro lado, a praticidade dos novos cortes casava muito bem com a dinâmica do capitalismo, pois,

[...] na era dos automóveis e dos esportes, era preciso ser prático e rápido. Cabelos longos, penteados complicados, chapéus grandes, saias de tecido grosso e a compressão do espartilho entravavam os movimentos que doravante precisavam ser de outra ordem: a vida metropolitana exigia um corpo menos arredondado, leve, impecavelmente liso e esguio" (SANT'ANNA, 2012, p. IO7).

$\mathrm{Na}$ década de 1960, em meio à revolução sexual e à segunda onda do Movimento Feminista, assistimos à disseminação das bonecas Barbie, que acabaram por se tornar um protótipo de corpo feminino. Com sua cintura finíssima, pernas longilíneas e seios empinados, essa boneca inspirou um modelo de corpo e beleza por muito tempo. As princesas da Disney também ajudaram a perpetuar esse ideal de corpo feminino, com seus corpos magros, cabelos escovados, traços e formato do rosto delicados.

Percebe-se que, ao serem criados esses padrões de beleza e comportamento, há a intenção de forjar uma essência feminina, que mesmo quando diz que está rompendo com algum padrão, na verdade, lança outro. Tania Swain (20I2, p. IO) ressalta que "a mídia continua a construir e divulgar as imagens 'da mulher', sujeito unificado, singular, reagrupando todas as mulheres em torno da modelagem dos corpos, da sensualidade, da sedução, ao lado da 'verdadeira mulher', a mãe e esposa”. Os corpos são concebidos como produtos em série. A publicidade divulga protótipos de corpos que, para serem alcançados exigem, muitas vezes, intervenções cirúrgicas e, se formos analisar bem, levam à anulação das singularidades, uma vez que padronizam elementos como seios, lábios, narizes, nádegas e tantos outros, conferindo-lhes formatos similares em nome de uma beleza uniformizada.

\footnotetext{
I De acordo com Denise Bernuzzi de Sant'Anna (2012, p. I07), "esse corte de cabelo foi criado em I926, três anos depois da importante descoberta da tumba de Tutankamon, quando, em várias partes do mundo, os tesouros e joias do antigo faraó egípcio serviram de inspiração à moda. A imagem egípcia de um porte vertical e cilíndrico combinava de modo surpreendente com a valorização do aerodinamismo."
} 
A preocupação com a beleza e a estética está sempre se renovando a partir da sua difusão em diversas instâncias midiáticas e, também, através da incorporação de novas ferramentas que prometem não só proporcionar uma bela aparência física, mas apresentamse relacionadas, ainda, ao bem-estar emocional e à saúde como uma receita de felicidade ou “poção mágica”, capazes de resolver todos os problemas - por isso é tão difícil escapar do seu alcance.

Procuro evidenciar, com esses apontamentos, que os discursos que circulam na contemporaneidade utilizam de instrumentos e práticas de subjetivação cada vez mais eficientes e sofisticadas que tornam a velhice e a morte algo vergonhoso - como assinala Michel Foucault (2000) ao cunhar o conceito de biopoder -, e investem assim sobre os corpos no sentido de maximizar a vida, dizendo às pessoas o que devem fazer para alcançar a longevidade e não permitir que as marcas do tempo se manifestem na sua aparência física. Com isso, os corpos tornaram-se "instituições performantes [...] que carregam significados, tornam carne representações e discursos que operam, no detalhe, o controle, a vigilância, o enquadrinhamento, a fixidez." (GOELLNER, 2008, p. 246). Cria-se, assim, um culto à juventude.

Mas, mesmo diante de uma grande oferta de possibilidades que prometem levantar a autoestima, proporcionar bem-estar e satisfação, há também limites, principalmente para as mulheres, que devem evitar os excessos. Elas precisam ser belas, mas dentro de normas fixas e preestabelecidas, "nada que desestabilize representações e discursos minuciosamente construídos sobre seus corpos, suas aparências e sua funcionalidade" (GOELLNER, 2008, p. 249). Por isso, as mulheres que dão aos seus corpos músculos mais definidos são, comumente, criticadas e repudiadas, pois na lógica desse discurso que elege o belo e o grotesco, elas colocam em risco não só sua suposta feminilidade, mas também desviam a atenção da função essencial do seu corpo: a procriação.

Há, portanto, um grande investimento nos corpos e basta acessar páginas da internet, ir a uma banca de revistas ou ligar a TV para perceber isso. Existe também, cada vez mais, uma associação entre o corpo saudável e uma estética padronizada que remetem à juventude.

De acordo com as mais diversas imposições culturais, nós os construímos de modo a adequá-los aos critérios estéticos, higiênicos, morais, dos grupos a que pertencemos. As imposições de saúde, vigor, vitalidade, juventude, 
beleza, força são distintamente significadas, nas mais variadas culturas e são também, nas distintas culturas, diferentemente atribuídas aos corpos de homens e mulheres. Através de muitos processos, de cuidados físicos, exercícios, roupas, aromas, adornos, inscrevemos nos corpos marcas de identidades e, consequentemente, de diferenciação (LOURO, 2000, p. 8-9).

Tendo em vista que o cinema como discurso artístico é uma tecnologia de gênero "com poder de controlar o campo do significado social e assim produzir, promover e “implantar' representações de gênero"(DE LAURETIS, I994, p. 228), é preciso buscar - como sugere Teresa De Lauretis - nos space-offs $s^{2}$ dos aparelhos de poder-conhecimento, "criar novos espaços de discurso, reescrever narrativas culturais e definir os termos de outra perspectiva - uma visão de 'outro lugar'”, de modo a lançar os termos de uma construção diferente do gênero, que possam se afirmar no plano da subjetividade e da autorrepresentação, "nas práticas micropolíticas da vida diária e das resistências cotidianas que proporcionam agenciamento e fontes de poder ou investimento de poder". Sendo assim, os filmes Shrek são aqui essa brecha para contestarmos alguns discursos hegemônicos a respeito dos corpos e das concepções de beleza.

\section{Shrek e Fiona: entre rupturas e permanências}

A história dos filmes Shrek constitui-se em um conto de fadas às avessas. Shrek é o anti-herói que cativa o público por não ter preocupação alguma em ser agradável; é egoísta, malcheiroso, não tem bons modos (no início do primeiro filme já aparece soltando peidos e arrotos) e, com sua aparência verde e corpulenta, causa repulsa nas demais personagens, fazendo inclusive murcharem as flores e vergarem as árvores por onde passa. Até mesmo o motivo que o leva a salvar a princesa gira em torno de interesses próprios: ao ver seu pântano invadido pelos vários personagens das histórias infantis e perturbado o seu sossego, Shrek vai em busca da princesa Fiona, condição imposta por Lord Farquaad para receber as criaturas mágicas novamente em seu reino, e devolver a quietude aos domínios do ogro.

\footnotetext{
${ }^{2}$ Lauretis ressignifica o termo space-off, retirado da teoria do cinema, "como espaços nas margens dos discursos hegemônicos, espaços sociais entalhados nos interstícios das instituições e nas fendas e brechas dos aparelhos de poder-conhecimento." (LAURETIS, 1994, p. 237).
} 
Os filmes apresentam ainda personagens singulares, como uma Fada-Madrinha ambiciosa; um príncipe pedante, interesseiro e covarde (Farquaad) e outro vaidoso, artificial e extremamente preocupado com a aparência (Encantado); um Lobo Mau que passa todo o tempo vestido de vovozinha e o Pinóquio, que gosta de usar roupas íntimas femininas; além do dragão que vigia o castelo, representante de força e ferocidade, tradicionalmente constituinte do gênero masculino, mas que na obra trata-se de uma fêmea que acaba se apaixonando pelo Burro, companheiro de aventuras de Shrek.

Outro momento de ruptura com os convencionais contos infantis e os papéis tradicionais de gênero se dá no resgate de Fiona, que havia idealizado tal momento como sublime, onde o cavalheiro lhe recitaria um poema épico, a tomaria nos braços e desceria por uma corda até sua bela montaria. Mas Shrek, preocupado em terminar logo sua tarefa, a sacode com força para acordá-la do suposto sono e apenas a coloca sobre os ombros e sai correndo para fugir do dragão, sem nenhum romantismo.

A Princesa Fiona, apesar de apresentar, a princípio, um discurso idealizado em relação ao amor e ao cavaleiro que a salvaria, também é uma mulher bastante prática e independente, que luta contra um grande número de homens sozinha utilizando golpes marciais, come ratos no espeto e até arrota, deixando Shrek e o Burro perplexos diante da sua postura autossuficiente e descontraída - bem diferente das princesas apresentadas nos contos tradicionais, geralmente frágeis, românticas e dependentes.

Por ter sofrido vários desdobramentos, a história de Shrek e Fiona mostra o que acontece depois do casamento e do "felizes para sempre", problematizando as dificuldades do relacionamento e a chegada dos filhos. No filme são abordadas ainda questões como alteridade, a intolerância ao diferente, a necessidade de se enquadrar em padrões de beleza e comportamento fixados pela sociedade e os relacionamentos humanos.

Também são apresentadas, nessa nova configuração das histórias infantis, diferentes identidades de gênero e formas plurais de vivenciar a sexualidade, como é o caso das personagens trans Dóris e Mabel, originalmente as "irmãs feias" da Cinderela. Tudo isso pode ser entendido como resultado das modificações vividas na contemporaneidade e dos impactos dos estudos de gênero, que ganham uma visibilidade maior a partir da atuação da mídia e dos novos mecanismos tecnológicos. 


\section{Beleza e felicidade num toque de condão}

O grande investimento no culto à juventude e a determinados modelos corpóreos leva diversas pessoas, sobretudo as mulheres, a empreenderem uma árdua luta em busca de uma estética construída pela publicidade. O dilema vivido pela personagem Fiona, no primeiro filme, ilustra o conflito de várias mulheres que oscilam entre o que é colocado socialmente como meta e ideal de beleza, inclusive por elas mesmas, encarnado na figura de Fiona humana - com sua silhueta delgada e curvilínea -, e o pesadelo do corpo gordo que as atormenta, representado pela imagem de Fiona ogra. A própria princesa, antes de se tornar a ogra confiante e bem resolvida com o próprio corpo - que percebemos do segundo filme em diante -, também perseguia o ideal do corpo magro e acreditava que a única forma de sentir-se bem e feliz era se livrando da condição e da aparência de ogra, pois, segundo ela, "princesa e feiura não combinam" e ninguém gostaria dela com tal aspecto.

Fiona reproduz esse tipo de discurso porque passou a vida sendo subjetivada nesse sentido, acreditando que ser ogra era algo ruim, que somente o beijo do amor verdadeiro a libertaria dessa condição e que nada poderia fazer além de esperar por ele. Em seu diário de adolescente ela registra alguns desses ensinamentos: "A mamãe disse que quando eu tiver idade, um lindo príncipe encantado irá me salvar da torre e me trazer de volta para a minha família. E vamos viver felizes para sempre”. (SHREK, PDI/DreamWorks, 2004. Grifos meus). A esses escritos seguem-se uma ilustração feita por Fiona onde aparecem ela, um príncipe e três crianças, e repetidos dizeres de "Senhora Fiona Encantado". Em vários momentos da história ela reitera esse discurso e o de como deve ser uma princesa:

Eu sou uma princesa e não é assim que uma princesa deve parecer [se referindo à identidade ogra]. Olha bem pra mim, Burro. Pensa bem, quem poderia amar um monstro tão nojento e feio. Princesa e feiura não combinam. [...] Minha única chance de viver feliz para sempre é me casar com meu verdadeiro amor. É assim que tem de ser. (SHREK, PDI/DreamWorks, 200I. Grifos meus).

O trecho em destaque deixa evidente que Fiona condiciona sua felicidade ao matrimônio e se conforma com esse destino simplesmente porque "é assim que tem de ser". Ela é uma princesa, uma mulher, e é isso que a vida reserva para o gênero feminino. É uma concepção determinista e generificada diante da qual ela não vê saída. 
Por isso, quando mais tarde Fiona opta pela manutenção da sua identidade ogra, mesmo que seja em nome do dispositivo amoroso - para que ela forme um par romântico harmonioso com Shrek -, o filme tem o mérito de apresentar outra representação de princesa e de beleza feminina que, se não consegue romper com o estereótipo esbelto, ao menos apresenta uma possibilidade diferente de conceber a beleza e de promover a identificação de uma parcela do público feminino.

Essa preocupação com a forma física não é recente e, desde que o biquíni ganhou popularidade nos anos 1960, o corpo feminino passou a ser alvo de uma atenção ainda maior, o que fez "os regimes para emagrecer dominarem a maior parte dos conselhos dirigidos à mulher, momento em que a celulite foi inventada", como ressalta Carla Bernuzzi de Sant'Anna (2012, p. II9).

A preocupação com a celulite e o peso cerca as mulheres por todos os lados. E isso também acontece com Fiona quando, triste, na varanda da sua casa, recebe a visita da FadaMadrinha, que canta para ela a seguinte canção com dicas para acabar com sua tristeza:

Só com um toque do meu condão

Não há mais preocupação

O seu príncipe logo vai surgir

Com muito ouro a reluzir

Vestido assim todo de cetim

Cristais reluzentes e jasmim

Não há mais por que se preocupar

A sua mobília vai te ajudar

Você vai ver sua estrela brilhar

Irresistível, linda demais

Mil príncipes correndo atrás

Seu nome nunca vai esquecer

Para um final feliz eles querem você

A carruagem que emoção

E um cocheiro bonitão

Os dentes mais brancos irão surgir

A celulite vai sumir (...)

Pó de arroz e batom

A aparência que dá o tom

Exercícios e jejum 


\author{
Sem contar o melhor bumbum \\ E pra comer só Buffet \\ Príncipe amado dançar com você \\ Vão deitar ao luar \\ Mil canções vão cantar \\ Que salão, que mansão \\ Com dinheiro de montão
}

(SHREK, PDI/DreamWorks, 2007. Grifos meus).

É possível perceber uma afinidade entre a mensagem transmitida pela canção e o discurso da mídia presente, sobretudo, nas chamadas "revistas femininas" com dicas de como resolver seus problemas amorosos, com o peso e a aparência física em um "passe de mágica" em enunciados do tipo: "perca um quilo por dia com a sopa milagrosa" ou "dieta do carboidrato", "do abacaxi" e tantas outras receitas absurdas que podem ser acessadas em uma rápida busca pela internet, e que podem até colocar em risco a saúde física e mental das mulheres.

Os conselhos da Fada-Madrinha estabelecem, também, um interdiscurso com "as publicidades de cosméticos e cremes rejuvenescedores [que] apelam à eterna juventude, ao corpo produzido: o modelo corporal está finalmente ao alcance de todas, na luta contra o tempo e as imperfeições" (NAVARRO-SWAIN, 200I, p. 72).

A música toca em vários pontos que passaram a ser motivo de preocupação para muitas mulheres como dietas, exercícios e a eliminação da indesejada celulite. E podemos notar que a sua letra faz eco a uma associação bastante corriqueira feita pela publicidade entre corpo perfeito e uma vida amorosa bem sucedida, pois, como sublinha Tania Swain, de acordo com o discurso da cosmetologia - e podemos acrescentar nesse pacote, também, dos defensores das cirurgias plásticas -, "nenhuma mulher precisa ser feia, uma vez que a beleza é condição sine qua non para o romance e a felicidade." (NAVARRO-SWAIN, 200I, p. 72).

De acordo com o texto grifado na letra da canção, possuindo um belo sorriso (e isso pressupõe os dentes mais brancos), um corpo sem celulite - conquistado através de jejuns e exercícios -, e roupas bonitas, joias e maquiagem, uma mulher torna-se irresistível e capaz de atrair diversos homens ("mil príncipes correndo atrás"), pondo fim a qualquer preocupação que possa vir a ter. Dentro desse discurso, o autocuidado feminino está a serviço de despertar o interesse masculino, e a mulher torna-se um adorno, um objeto cuja 
principal finalidade é apresentar-se à contemplação já que, como sugere a letra, "é a aparência que dá o tom".

Esse discurso deixa subentendida uma heterossexualidade compulsória e atrela a felicidade feminina à conquista de um parceiro. A Fada-Madrinha encarna, assim, o papel da sociedade de consumo - enumerando uma ampla quantidade de serviços e produtos a serem consumidos para atingir a felicidade - e da mídia voltada para a beleza e que faz os desejos parecerem uma necessidade, tanto que fica espantada quando Fiona diz a ela que não precisa de nada daquilo para ser feliz.

Em Shrek 2, a ideia de que só se atinge a felicidade possuindo rostos e corpos belos é novamente problematizada quando Shrek, achando que Fiona está infeliz por ter a aparência de uma ogra, sai em busca de um feitiço ou poção mágica que possa dar a eles um "felizes para sempre", e esse estado de espírito estaria condicionado à aparência física. Chegando à indústria de poções, a Fada-Madrinha subtrai dele essas pretensões dizendo que os ogros não têm finais felizes. Neste momento, ela consulta vários livros de contos de fadas e em nenhum deles aparece um ogro com final feliz, mesmo porque, nos contos tradicionais, a feiura aparece associada quase sempre aos personagens ruins, que por causa das suas maldades precisam ser punidos.

Mesmo assim, decidido a agradar sua amada a qualquer custo, Shrek, Burro e o Gato de Botas roubam a poção "Felizes para sempre" que, na bula, promete proporcionar "felicidade, amor e beleza divina". O resultado, ao ingerir a poção, que pode ser conferido nas imagens da figura I, é uma mudança na forma física de Shrek, Fiona e Burro, que também bebeu da poção, assumindo feições graciosas e aparência humana e, no caso deste último, a de um alazão. Importante salientar a crítica de que, sob uma determinada ótica, dentro da sociedade, como indica a descrição dos efeitos da poção, a felicidade é, muitas vezes, o resultado de uma beleza estética. 


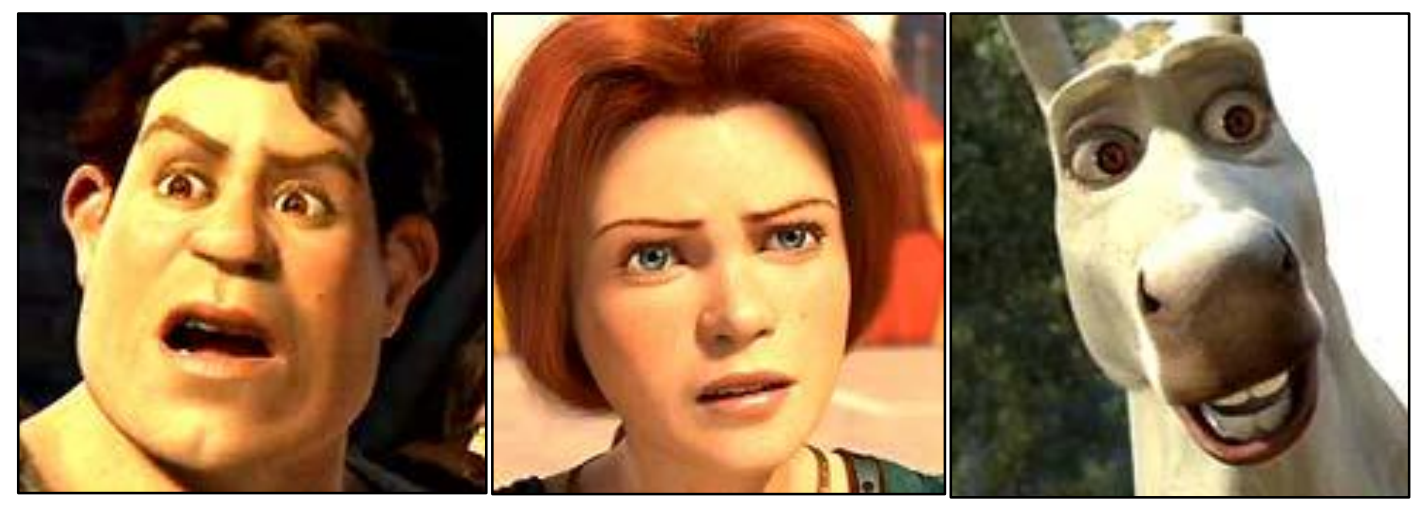

Figura I: Shrek, Fiona e Burro depois de tomarem a poção "Felizes para sempre". Fonte: http://www.filmsite.org/series-shrek2.html.

No terceiro filme, Fiona e Shrek tentam novamente se enquadrar no modelo de membros da realeza. A imagem a seguir ilustra essa tentativa de adequação, que fracassa, levando a uma enorme confusão. Nessa cena, Fiona é obrigada a usar o espartilho ${ }^{3}$ para esconder sua barriga saliente e afinar a silhueta, e Shrek, um cinto bem apertado. Ambos são maquiados e recebem perucas, figurino que remete às vestimentas usadas na era vitoriana. A ideia transmitida pela cena é de que não basta ser um membro da realeza, é preciso se parecer com um.

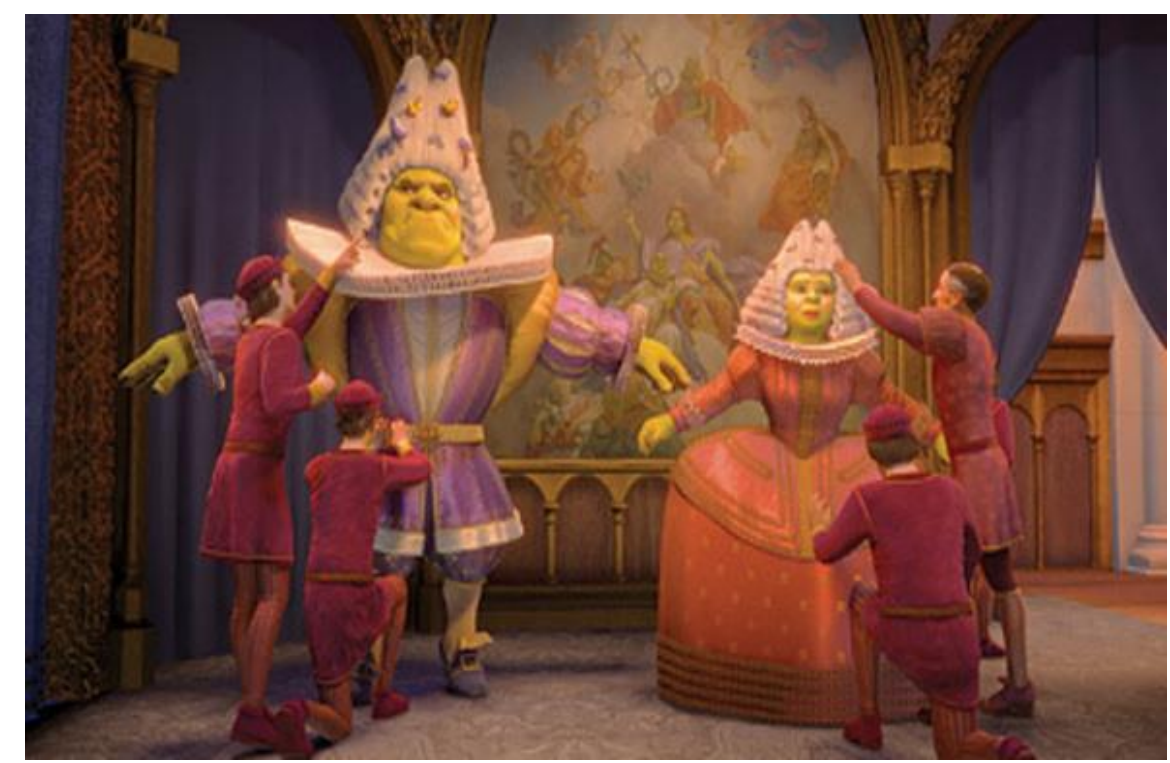

Figura 2: Shrek e Fiona se preparando para assumir o trono

Fonte: http://www.recreio.com.br.

\footnotetext{
3 O espartilho, surgido no século XVI e muito comum nas vestimentas das mulheres do século XIX, voltou com força total neste início de século como acessório de moda, e em grande medida através da prática do tight lacing, que utiliza essa peça como instrumento para modelar a cintura e perder medidas.
} 
Outro momento que aborda a questão da beleza se dá durante uma reunião entre as princesas, para uma espécie de chá de bebê. Em um diálogo fútil e superficial, Branca de Neve, Cinderela, Rapunzel e Bela Adormecida dão conselhos a Fiona sobre casamento e filhos, mesmo sem terem vivido essas experiências. Dóris, a irmã feia, também está presente e se solidariza com Fiona, dizendo que o bebê só vai aumentar o amor existente entre os dois. Durante o chá, Fiona recebe alguns presentes curiosos: pá para recolher os cocôs do bebê e um dos sete anões para servir de babá. O fotograma a seguir nos dá um panorama do diálogo que vem na sequência:

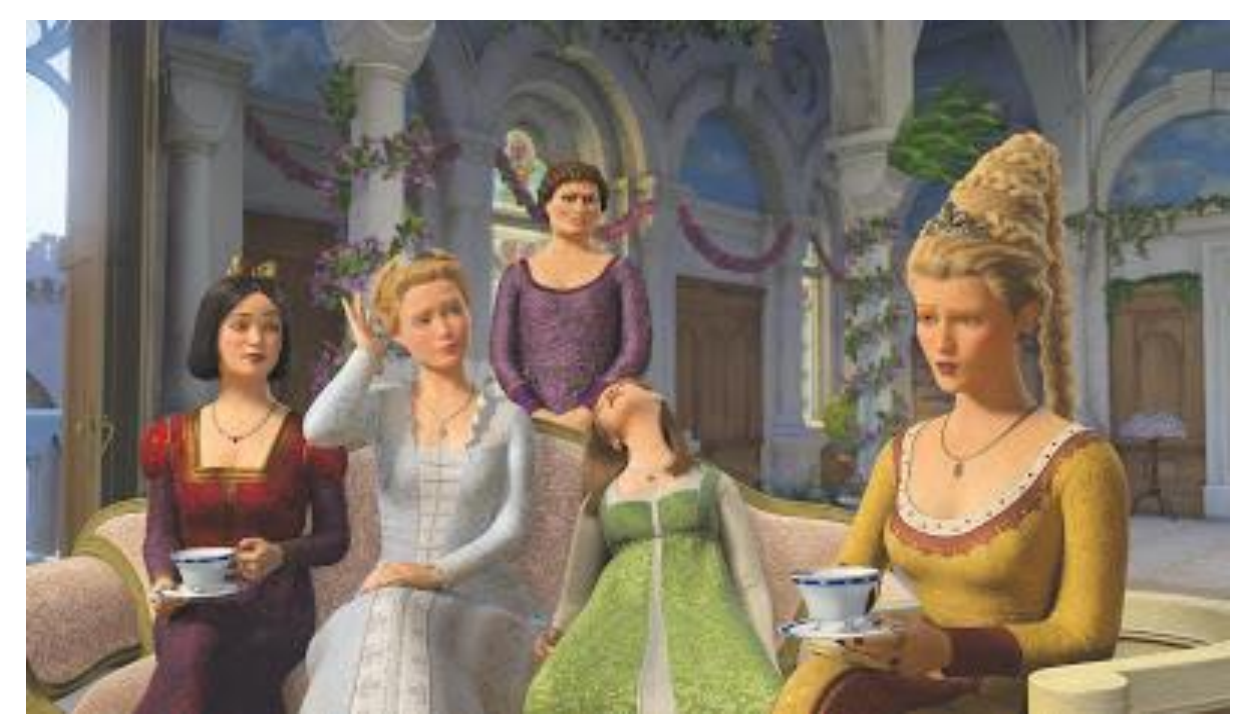

Figura 3: Reunião das Princesas - Chá de bebê da Fiona

Fonte: http://www.cinepop.com.br/

Cinderela: Ai, Fiona abre o meu primeiro? É esse aí na frente.

Fiona: (lendo o cartão) 'Meus parabéns pelo seu primeiro fedorentinho.

Espero que seja útil. Com amor, Cinderela'.

Cinderela: É para o cocozinho.

Bela Adormecida: Eca, como? Bebê faz cocô?

Rapunzel: Todo mundo faz cocô, Bela.

Branca de Neve: Eu comprei o maior de todos porque eu te amo mais.

Fiona: (lendo o cartão) 'Esse é para você. Beijos, Branca de Neve'.

Fiona: O que é isso?

Branca de Neve: É uma minibabá.

Fiona: Bem, e o que ele faz?

Branca de Neve: Ele limpa, dá comida, faz arrotar... 
Fiona: E o que eu e o Shrek vamos fazer?

Rapunzel: Bom, agora vai ter tempo para cuidar do seu casamento.

Fiona: Poxa, obrigada, Rapunzel. O que quer dizer com isso?

Rapunzel: Ah, ora, vamos, Fiona, você sabe muito bem como é...

Bela Adormecida: Vai estar cansada o tempo todo.

Branca de Neve: Aí começa a se descuidar.

Boneco: Vêm as estrias.

Rapunzel: Não há amor que resista.

(SHREK, PDI/DreamWorks, 2007)

O diálogo instantaneamente desconstrói a ideia de que princesas são seres que não possuem necessidades fisiológicas ou que são excessivamente bondosas, mas também as caracteriza como pessoas frívolas. Levanta, ainda, a dinâmica que supostamente envolve o casamento e o temor que obriga as mulheres a se cuidarem para não serem trocadas por outra - quando o mesmo não ocorre em relação aos homens. A cena cria, ao mesmo tempo, uma dicotomia que opõe beleza e inteligência, pois de um lado temos as belas, mas superficiais, princesas, e de outro, a ogra Fiona e a transgênera Dóris, que se mostram mais sensatas, porém, não se encaixam no padrão de beleza ocidental preconizado pela mídia.

A preocupação manifestada pelas princesas quanto à aparência física de Fiona após a maternidade pode ser percebida nos vários discursos que nos cercam na contemporaneidade, conforme ressalta Silvana Vilodre Goellner:

A espetacularização dos corpos femininos pode ser observada em várias instâncias culturais tais como revistas, peças publicitárias, programas televisivos, cartazes, filmes... Os corpos lá representados inscrevem-se no que denomino de "imperativo da beleza": conjunto de ações voltadas para a construção de práticas e discursos que tomam a beleza como uma obrigação. Uma meta em função da qual as mulheres devem investir esforços, energias, dinheiro e emotividades. Sob os auspícios de discursos médicos e hedonistas, inúmeras prescrições são direcionadas para a edificação deste imperativo, cuja rede de poderes a ele associado investe o corpo feminino como objeto de consumo próprio e também de uma sociedade que tem na aparência corporal um dos marcadores da identidade dos sujeitos. (GOELLNER, 2008, p. 250) 
A "necessidade" da maternidade e o "instinto materno", que estão implicitamente presentes na cena e no diálogo entre as princesas e Fiona, são considerados por Tania Swain como uma criação social que se perpetua pela repetição constante das normas heterossexuais e reprodutivas. Assim, o "eterno feminino" se atualiza, o tempo todo, nas tecnologias de reprodução do gênero, reforçando o discurso de que as mulheres "não encontram a plenitude de seus corpos constituídos em sexo senão em sua função reprodutora”. (NAVARRO-SWAIN, 20I2, p. 9). Para a autora,

[...] a imagem e os sentidos atribuídos aos corpos não são, portanto, superfícies já existentes sobre as quais se encastram os papéis e os valores sociais; são, ao contrário, uma invenção social, que sublinha um dado biológico cuja importância, culturalmente variável, torna-se um destino natural e indispensável para a definição do feminino. (NAVARRO-SWAIN, 20I2, p. 6).

$\mathrm{Na}$ sequência da cena descrita anteriormente, as princesas descobrem que o reino está sendo invadido pelos vilões das histórias infantis que, liderados pelo Príncipe Encantado, as aprisionam. Depois de um momento de subordinação e apatia, onde elas reproduzem discursos tradicionais e machistas, Fiona as convence da necessidade de se organizarem para uma reação: "É isso aí, meninas, de agora em diante vamos cuidar de tudo sozinhas”. As princesas unem-se, então, para tentar derrubar Encantado do poder, e, simbolicamente, numa alusão ao movimento feminista, queimam um sutiã e partem para a luta. Essa simbologia evidencia como este movimento foi e é um importante conscientizador para que as mulheres se reconheçam como sujeitos políticos e agentes da sua história, tirando-as da inércia e da submissão, como aconteceu com as personagens. 


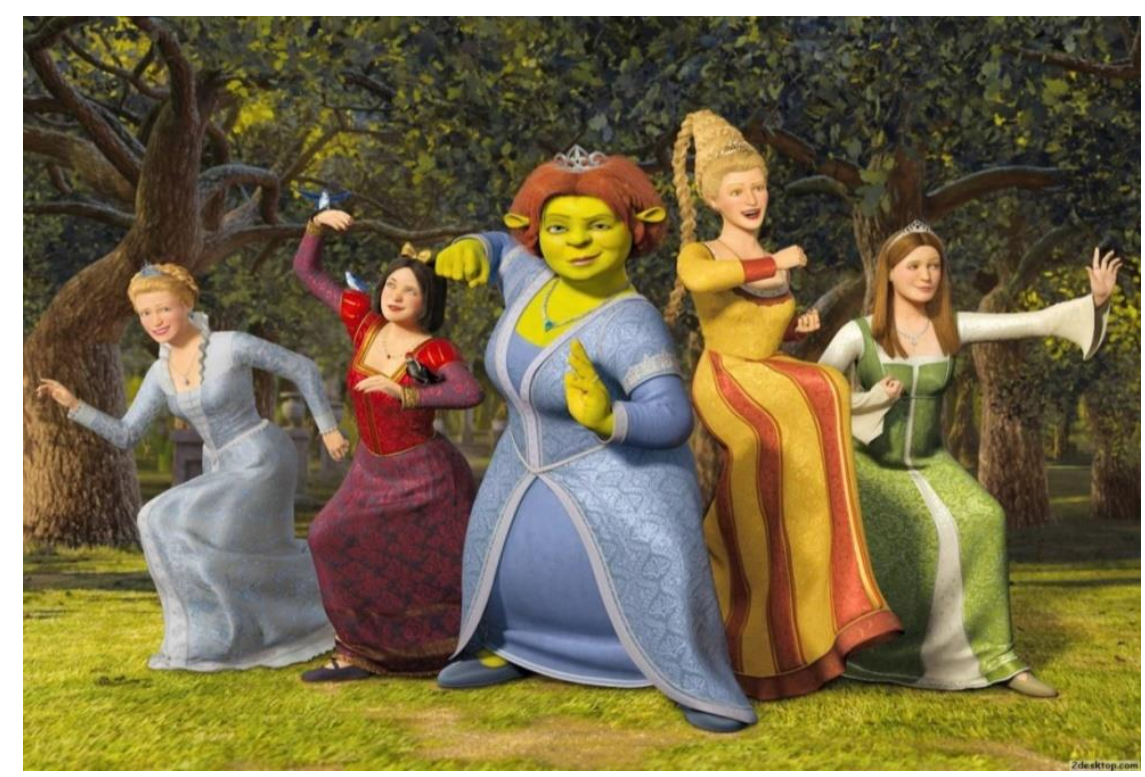

Figura 4: Princesas em ação. Fonte: http://sinopse365.blogspot.com.br.

A comparação das duas imagens relativas às princesas possibilita uma visualização da drástica diferença da postura assumida por elas. De apáticas e dependentes, elas se tornam guerreiras destemidas: Branca de Neve rasga a manga do vestido, deixando à mostra uma tatuagem; Bela Adormecida rasga a barra do vestido e Cinderela afia os sapatinhos de cristal; a rainha Lílian, depois de ter derrubado as paredes da prisão com golpes de cabeça, faz no rosto marcas de guerra com o batom. Diante do ar de admiração e espanto de Fiona, sua mãe ainda diz: "ora, ou você pensou que sabia lutar bem porque havia puxado ao seu pai?". Juntas, elas traçam estratégias de luta, que vão da sedução ao combate corpo a corpo, utilizando golpes marciais. Ao assumirem o comando da situação, as princesas mostraram que é possível superar as condições de submissão e assujeitamento. Nesse momento, elas se reconheceram como autoras do seu próprio destino.

\section{Considerações finais}

O estudo desses filmes aqui apresentados evidencia que as preocupações com o corpo e a beleza, e as posturas, ora de passividade, ora aguerridas, fazem parte da construção fílmica das personagens em Shrek, que em alguns momentos reforçam e em outros rompem com os estereótipos de feminilidade, situação que pode ser percebida na própria dinâmica social do cotidiano. Notamos, no percurso dessa análise, que os corpos são alvo de investimentos constantes, seja sobre sua funcionalidade, seja sobre sua estética. E a sexualidade feminina é alvo ainda mais constante das coerções e disciplinas. 
Outra constatação é que essa nova safra de animações e adaptações dos contos de fadas, ainda que com muitas permanências de comportamentos tradicionais, demonstram uma preocupação efetiva em retratar as diferentes configurações nas relações e representações de gênero, rompendo, pelo menos em parte, com a dicotomia masculino $\mathrm{x}$ feminino, bem x mal, belo x feio, e descortinando um cenário social que é muito mais complexo. A superação dessa lógica binária é fundamental para a construção de um novo olhar aberto às diferenças.

A preocupação demonstrada pelas personagens em relação à estética de seus corpos e a associação da aparência física à conquista de um par romântico permitem perceber que debater questões como gordofobia, pressão estética e a objetivação dos corpos femininos é urgente. É preciso contestar a imagem da princesa cuja existência é voltada para agradar o parceiro ou de um corpo para procriar, que, além disso, precisa estar sempre magro para não correr o risco do abandono e da solidão. Contestar esses modelos é imprescindível para concebermos um olhar mais plural a respeito da beleza.

Apesar das mudanças contemporâneas nas relações de gênero, muitas animações como as discutidas aqui - insistem na naturalização do papel procriativo e das relações heteronormativas, onde se celebram a união do casal de protagonistas consagrada pelo casamento e o nascimento de muitos bebês. Isso faz com que os corpos das mulheres sejam insistentemente associados à maternidade. Mesmo assim, o lançamento dos filmes Shrek se tornou um marco na história do cinema de animação, tanto que a partir daí vários filmes passaram a inserir em seus enredos as discussões sobre as construções e representações de gênero. O intento maior deste trabalho foi justamente suscitar o debate, o confronto de opiniões que se torna possível, sobretudo, pelo acesso rápido e fácil aos filmes. Isso fez com que eles se tornassem, inclusive, um produto de consumo em massa.

\section{Referências bibliográficas:}

DE LAURETIS, Teresa. A Tecnologia do gênero. In: HOLLANDA, Heloisa Buarque de. Tendências e impasses: o feminismo como crítica da cultura. Rio de Janeiro: Rocco. I994. FOUCAULT, Michel. Em defesa da sociedade. São Paulo: Martins Fontes, 200.

GOELLNER, Silvana Vilodre. A cultura fitness e a estética do comedimento: as mulheres, seus corpos e aparências. In: STEVENS, Cristina Maria Teixeira; SWAIN, Tânia Navarro (Orgs). A construção dos corpos: perspectivas feministas. Florianópolis: Mulheres, 2008. 
LOPES, Eliane Teixeira. Prefácio - Vá ao cinema! In: TEIXEIRA, Inês Assunção de Castro; LOPES, José de Sousa Miguel (orgs). A mulher vai ao cinema. Belo Horizonte: Autêntica, 2008. LOURO, Guacira Lopes. Pedagogias da sexualidade. In: LOURO, Guacira (org.) O Corpo Educado: Pedagogias da Sexualidade. Belo Horizonte: Autêntica, 2000.

NAVARRO-SWAIN. A invenção do corpo ou "a hora e a vez" do nomadismo identitário. Disponível em: http://www.tanianavarroswain.com.br/chapitres/bresil/espelho,espelho.htm. Acesso em I8 set. 2012.

. Feminismo e recortes do tempo presente: mulheres em revistas "femininas". São Paulo Perspec., vol. 15 n $^{\circ}$ 3, São Paulo, July/Sept. 200I. Disponível em: < www.scielo.com.br $>$ Acesso em 13 fev. 2014.

SANT’ANNA, Carla Bernuzzi. Sempre bela. In: PINSK, Carla Bassanezi; PEDRO, Joana Maria (orgs.). Nova História das Mulheres no Brasil. São Paulo: Contexto, 2012.

SPINK, Mary Jane; MEDRADO, Benedito. Produção de sentido no cotidiano: uma abordagem teórico-metodológica para análise das práticas discursivas. In: SPINK, Mary Jane (org). Práticas discursivas e produção de sentidos no cotidiano. Rio de Janeiro: Centro Edelstein de Pesquisas sociais, 2013, p. 22-4I.

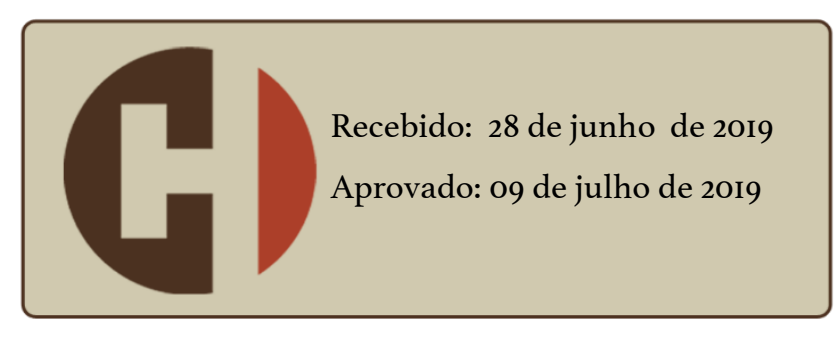

